Seven papers deal with meteorites, their origin, frequency of falls, radiation ages and composition. The longest of these gives a scholarly account of the classification of the chondrites on the basis of their chemical and pertrological composition. The abundance of uranium and thorium is discussed in relation to theories of the genesis of the elements, and finally ono paper discusses the chomical composition of comets.

All Urey's most speculative interests, the origin of the elements, the planets and life itself are represented. The volume is a worthy tribute to a remarkable man.

A. G. MADNOCK

\section{GEOLOGICAL AND CHEMICAL EVOLUTION OF EVAPORITES}

\section{Salt Deposits}

The Origin, Metamorphism and Deformation of Evaporites. By Prof. Hermann Borchert and Dr. Richard O. Muir. (The University Series in Geology.) Pp. $x+338$. (London and Princeton, N.J.: D. Van Nostrand Company, 1964.) $80 s$.

7 HIS translation of Hermann Borchert's important book Ozeane Salzlagerstatten (Geb. Borntraeger, 1959), with a considerable amount of material added by $R$. $O$. Muir, the translator, may justly claim to be the first comprehensive work in English on the natural salt deposits, the only previous approach to such a treatment being F. H. Stewart's chapter in the current revision of Clarke's Data of Geochemistry (U.S. Geol. Survey Prof. Paper 440-Y. Pp. 52. 1963). It is most valuable to have this summary from one of the leading European authorities, the more so because the deposits of the German Zechstein are considered at some length and these have probably been studied more intensely, and for a longer time, than any in the world.

In the case of the evaporites, as with marine iron ores, the 'principle of uniformity' cannot be applied, in that no extensive marine halite or potash accumulations can be observed in process of formation at the present. The factors controlling development and distribution of salt deposits, past and present, thus have to be inferred from geological evidence, and from the evidence of physical chemistry. After presenting a useful summary of the properties of the 26 important mineral phases found in evaporites, the first five chapters deal with depositional environment, distribution, sedimentation and tectonics, some emphasis being placed on the recurrent rhythmic nature of precipitation. Usiglio's contention that the necessary environment is a basin or series of basins with tectonic bars to control the influx of new sea-water is strongly upheld.

Isothermal evaporation of sea-water is next considered and the paths of crystallization illustrated in terms of the quinary system $\mathrm{Na}_{2}-\mathrm{K}_{2}-\mathrm{Mg}-\mathrm{Cl}_{2}-\mathrm{SO}_{4}$. Oceanographic studies show, however, that temperature and concentra. tion gradients exist in all basins, varying with changing current velocities to maintain a dynamic equilibrium. A brave attempt to consider the dynamo-polythermal evaporation of sea-water is therefore made and interesting comclusions are reached about the successive stages in primary facies variation as a basin becomes more isolated from the open sea.

It has long been known that profound mineralogical changes occur in complex salt deposits as they become more decply buricd, arising from the changed temperature-pressure conditions, and from the activity of solutions, especially those being eliminated from deeper levels. Writers in English have hitherto hesitated to describo these changes as metamorphic, since they occur under conditions where silicate minerals in sedimentation are undergoing the changes associated with diagenesis, below the lowest recognized grade of metamorphism. Nevertheless, the authors make a good case for describing the modifications in the evaporites as metamorphic and show that they can be considered in relation to the phase diagrams for various temperatures in the quinary system mentioned here, rather more effectively than silicates can be deciphered in terrns of present knowledge of the physical chemistry of such systems as $\mathrm{Na}_{2} \mathrm{O}-\mathrm{K}_{2} \mathrm{O}-\mathrm{CaO}-$ $\mathrm{Al}_{2} \mathrm{O}_{3}-\mathrm{SiO}_{2}$ at elevated temperatures. Chapters 8-15 deal with metamorphism and its consequences; with normal progressive motamorphism described in terms of melting and the activity of melt liquors; and with retrograde metamorphism deseribed in terms of the effects of water eliminated during dehydration reactions at greater depth and forced upward. The latter type of metamorphism is caused by dilute solutions percolating very slowly into salt deposits; besides waters originating as already noted from the conversion of gypsum $\left(\mathrm{CaSO}_{4} \cdot 2 \mathrm{H}_{2} \mathrm{O}\right)$ into anhydrite $\left(\mathrm{CaSO}_{4}\right)$ and similar sources, the possibility of activity by hydrothermal solutions of magmatic origin is contemplated, and the well-known solution effects due to metooric groundwater are also included. Here there are possible grounds for criticism, for changes taking place within the zone of circulating groundwaters do not form part of the silicate petrologist's conception of metamorphism. It must, however, be recognized that it is not easy to avoid this difficulty. The essential distinction between the two types of salt metamorphism proposed is that normal progressive changes are produced by authigenic liquors generated by geothermal melting, and lead to a scquence of mineral associations of which each successive one is in stable equilibrium with a liquid phase that becomes incroasingly rich in $\mathrm{MgCl}_{2}$. Retrograde changes, on the other hand, give rise to parageneses stable in brines becoming deficient in $\mathrm{MgCl}_{2}$, but increasingly sulphatic. With the basic conception of salt metamorphism established, it is possible to look at facies variations in the deposit and to attempt to assess their primary or secondary nature; and it is clear that very many have been influenced by post-depositional changes.

A variety of different evaporite districts are described, and there are interesting chapters on the mechanical properties of salts, on salt-tectonics, and on the relationship between evaporites and oil accumulations.

This book is a very important contribution to the literature of the subject, but it is aimed at the advanced student or the specialist, for its authors do not hesitate to enter into controversies the background of which can only be adequately known to those familiar with what has been written during the past two decades about evaporites in several different countries. A less-sophisticated version for the ordinary student of geology or ehemistry would also be welcome.

K. C. Dunham

\section{MAGNETISM AND LIFE}

\section{Biological Effects of Magnetic Fields}

Edited by Madeleine F. Barnothy. Pp. ix +324 . (New York: Plenum Press, 1964.) 16.00 dollars.

$B_{\text {IOLOGICAL Effects of Magnetic Fields is not, as might }}$ $\boldsymbol{B}$ besupposed, yet another report of a conference attended by workers with a common interest; it is rather a book designed "to provide a theoretical and practical background" for would-be research workers, and also to "bring together in one volume the present-day knowledge in all the active fields of biomagnetic rescarch". It is divided into four main sections: first, "Theoretical Considerations"; secondly, "Effects of Strong Magnetic Fields in Specimens in vivo"; thirdly, "Effect of Strong Magnetic Fields on Specimens in vitro"; and fourthly, "Effects of Very Weak Magnetic Fields". Finally, there is a fairly comprehensive bibliography relating to the effocts of static fields.

On the whole I must confess that I found the book disappointing. Perhaps a failure to achieve some sort of unified 